January 2013 Volume 128 Number 1

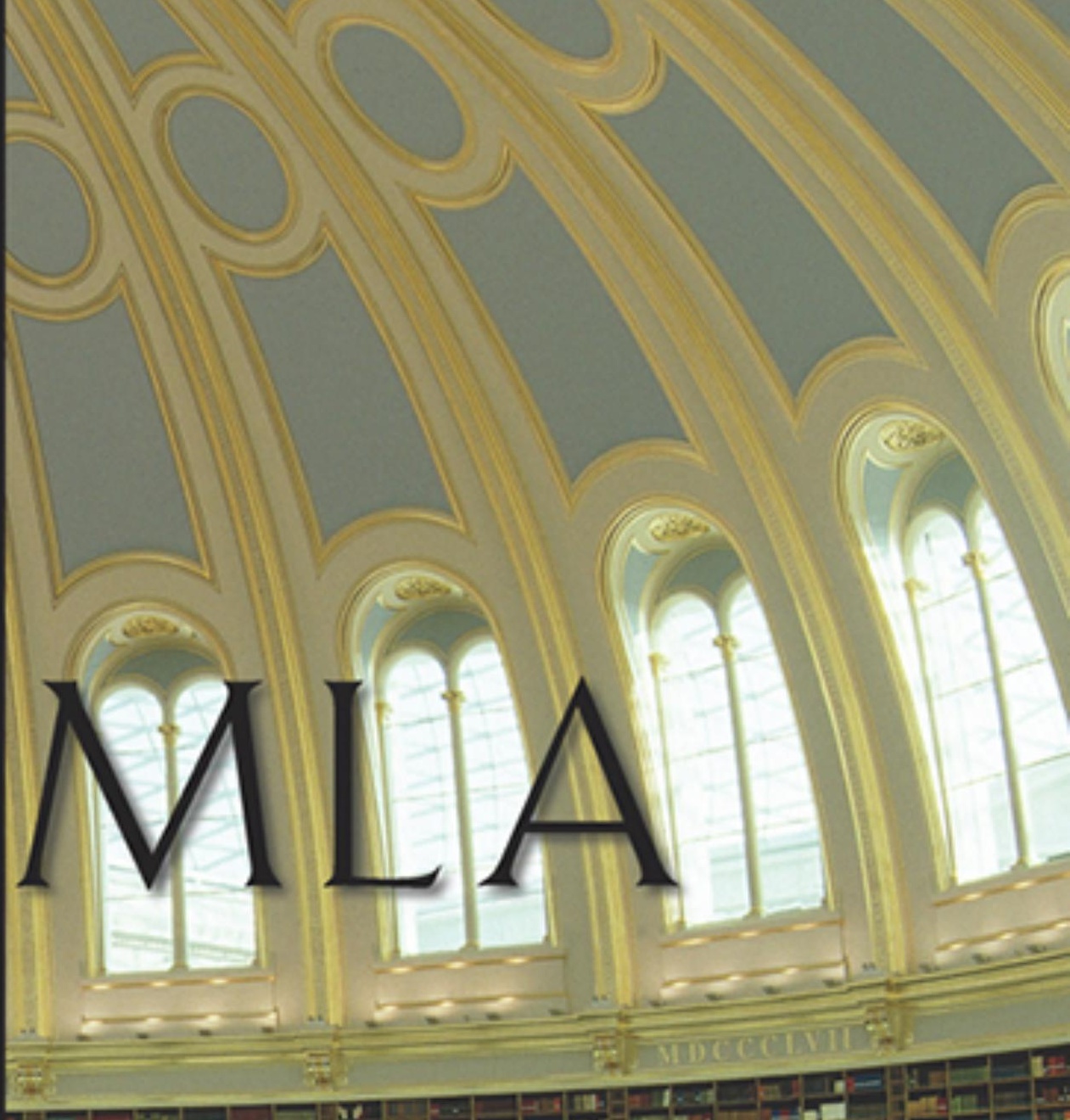

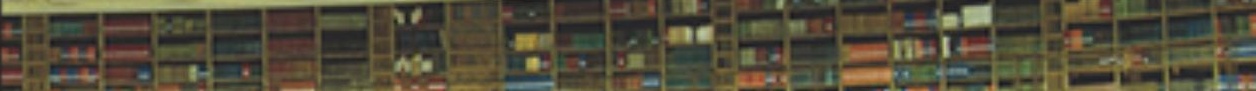
Fil Gi

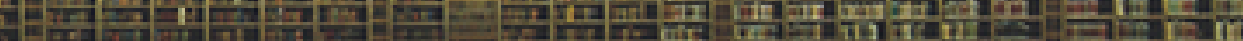

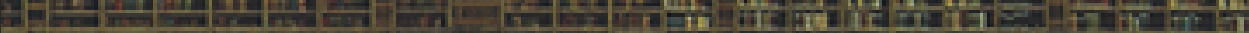

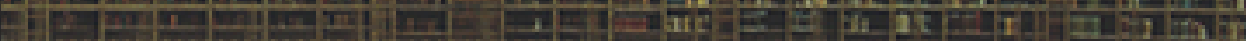

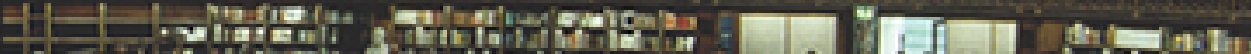

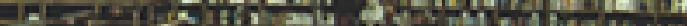

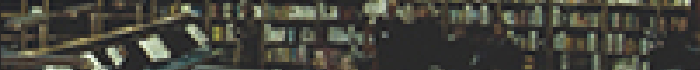

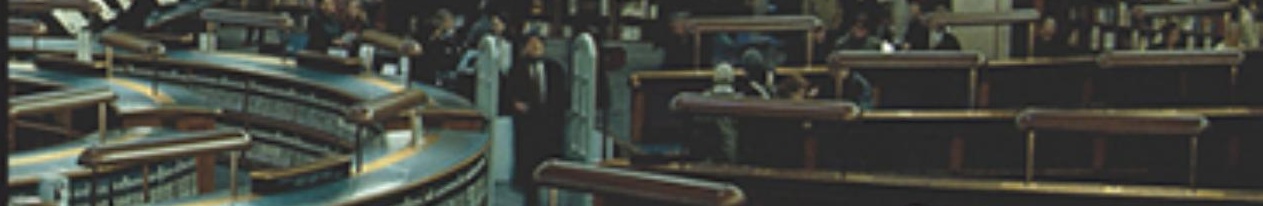
-

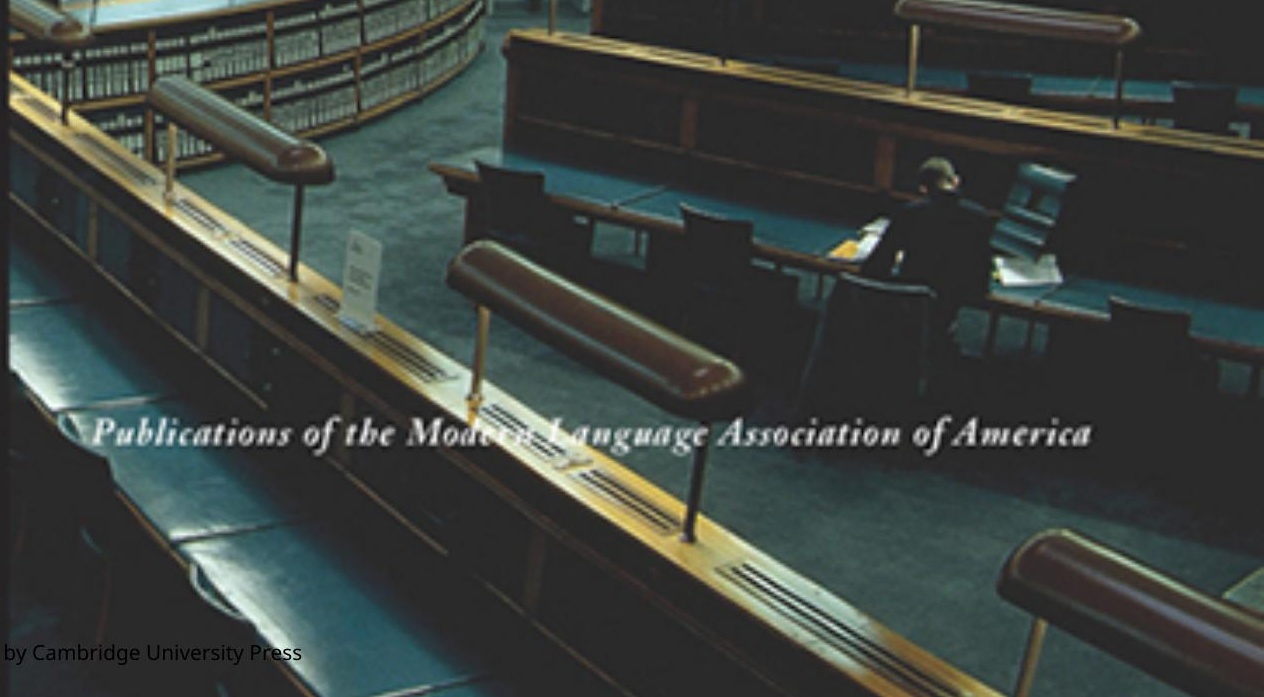




\section{January 2013}

Volume 128 Number 1

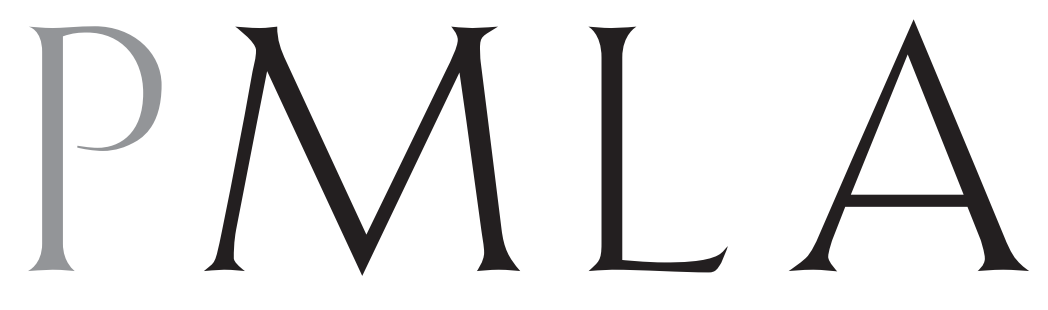

Publications of the Modern Language Association of America 
THE MODERN LANGUAGE ASSOCIATION OF AMERICA

[ Organized 1883, Incorporated 1900$]$

\section{Officers for the Term Ending 12 January 2014}

President: Marianne Hirsch Columbia University

First Vice President: Margaret W. FERGUSON

University of California, Davis

Second Vice President: Roland Greene Stanford University

Executive Director: Rosemary G. FeaL

\section{Executive Council}

FOR THE TERM ENDING 12 JANUARY 2014

JONATHAN ARAC

University of Pittsburgh

LAWRENCE I. BUELL

Harvard University

DOROTHEA HeITSCH

University of North Carolina, Chapel Hill

RICHARD M. OHMANN Wesleyan University

FOR THE TERM ENDING 11 JANUARY 2015

Barbara K. Altmann University of Oregon

Debra Ann Castillo Cornell University

María Herrera-Sobek

University of California, Santa Barbara

FOR THE TERM ENDING 10 JANUARY 2016

SAMER M. Ali

University of Texas, Austin

LANISA KITCHINER

Howard University

Lutz KoePNiCK

Washington University in St. Louis

Mecca Jamilah Sullivan

University of Pennsylvania

FOR THE TERM ENDING 8 JANUARY 2017

Alicia M. DE la Torre FalzoN

Northern Virginia Community College, Annandale Campus

Donald E. Hall

Lehigh University

Paula M. Krebs

Bridgewater State University

\section{Trustees of Invested Funds}

Herbert Lindenberger San Francisco, California

Malcolm B. Smith (Managing Trustee) New York, New York

Catharine R. Stimpson New York, New York
PMLA (ISSN 0030-8129) is published five times a year, in January, March, May, October, and November, by the Modern Language Association of America. Membership in the association is open to persons who are professionally interested in the modern languages and literatures. Annual (calendar-year) dues, which include subscription to $P M L A$, are $\$ 21$ for graduate student members (up to a maximum of seven years) and are based on income for regular members: income under $\$ 15,000, \$ 26$; income $\$ 15,000$ $\$ 20,000, \$ 42$; income $\$ 20,000-\$ 30,000, \$ 52$; income $\$ 30,000-\$ 40,000, \$ 73$; income $\$ 40,000-\$ 50,000$ $\$ 88$; income $\$ 50,000-\$ 60,000, \$ 104$; income $\$ 60,000-\$ 70,000, \$ 120$; income $\$ 70,000-\$ 80,000, \$ 135$; income $\$ 80,000-\$ 100,000, \$ 151$; income $\$ 100,000-\$ 120,000$, $\$ 172$; income $\$ 120,000-\$ 140,000, \$ 193$; in come $\$ 140,000-\$ 160,000, \$ 214$; income $\$ 160,000-\$ 180,000$, $\$ 240$; income $\$ 180,000-\$ 200,000$, $\$ 266$; in come over $\$ 200,000, \$ 292$. Joint membership, which provides one copy of the January, March, May, and October issues of PMLA but two copies of all other publications, is available to two individuals sharing the same household. The dues for a joint membership are $\$ 42$ above the dues that would be paid by the higher-income member alone. Foreign members pay the same as regular members (use the American dollar equivalent to ascertain the dues category). Membership applications are available on request and at the MLA Web site (www.mla.org).

For libraries and other institutions, a subscription in 2013 to the electronic format of PMLA alone is $\$ 190$ and to the print and electronic formats is $\$ 210$ (domestic and Canadian) or $\$ 240$ (foreign). Sub scriptions also include online access to the 2002-12 volumes. For an additional \$180, institutional subscribers receive a clothbound edition of the 2013 volume of $P M L A$. Agents deduct four percent as their fee. Claims for undelivered issues will be honored if they are received within six months of the publication date; thereafter the single-issue price will be charged. To order an institutional subscription, call or write the Member and Customer Services Office of the association (646 576-5166; subscrip@mla.org).

Single copies of the January, March, May, and October issues can be purchased for $\$ 12$ each; the November (Program) issue is $\$ 35$. Issues for the current year and the previous one are available at the MLA Bookstore (www.mla.org/store/CID70) and from the Member and Customer Services Office of the association (646 576-5161; bookorders@mla.org).

An online archive of PMLA issues from 1884 to 2007 is available through JSTOR (www.jstor.org).

Volumes up to 2000 can be obtained on microfilm from NA Publishing, Inc., 4750 Venture Drive,

Suite 400, PO Box 998, Ann Arbor, MI 48106-0998 (800 420-6272; www.napubco.com/umi.html).

The office of publication and editorial offices are located at 26 Broadway, 3rd floor, New York, NY 10004-1789 (646 576-5000; pmlasubmissions@mla.org).

All communications concerning membership, including change-of-address notifications, should be sent to the Member and Customer Services Office, MLA, 26 Broadway, 3rd floor, New York, NY 10004 1789 (646 576-5151; membership@mla.org). If a change of address also involves a change of institutional affiliation or a new e-mail address, that office should be informed of this fact at the same time.

Periodicals postage paid at New York, NY, and at additional mailing offices.

(c) 2013 by The Modern Language Association of America. All rights reserved. Printed in the United States of America.

MLA and the MODERN LANGUAGE ASSOCIATION are trademarks owned by the Modern Language Association of America.

Library of Congress Catalog Card Number 12-32040. United States Postal Service Number 449-660. POSTMASTER: Send address changes to PMLA, Member and Customer Services Office, MLA 26 Broadway, 3rd floor, New York, NY 10004-1789. 


\section{Contents}

JANUARY 2013

5 A Statement of Editorial Policy

6 Forthcoming in PMLA

6 Features in PMLA

8 Corrections

9 Editor's Column-The Fantasy of the Library

21 The New Unhistoricism in Queer Studies

Valerie Traub

Bede's Liberation Philology: Releasing the English Tongue Irina A. Dumitrescu

Homer in a Nutshell: Vergilian Miniaturization and the Sublime

Elizabeth Young

73 Whitman's Children

Peter Coviello

87 Auditory Exposures: Faulkner, Eisenstein, and Film Sound Sarah GleEson-White

\section{theories and methodologies}

\section{An African Classic in Fourteen Translations}

101 Ferdinand Oyono's Une vie de boy on the World Literary Stage David Chioni Moore

112 When Oyono's “Boy” Speaks Dutch: Two Readings in One Language Jeroen Dewulf

119 The Portuguese Translation of Oyono's Une vie de boy: José Saramago's Invisible Postcolonial Intervention

Ana Paula Ferreira

127 Oyono in Arabic

Waïl S. HASSAN

133 Circumcised or Cannibalized: Une vie de boy in Chinese Translation LUCAS KLEIN

142 Ferdinand Oyono's Flüchtige Spur Tundi Ondua and Germany's Cameroon VOLKer LANGBEHN

149 Majors and Minors in Europe's African Enterprise: Oyono's Une vie de boy in Danish and Swedish Translations

URSULA LINDQVisT
PUBLICATIONS OF THE MODERN

LANGUAGE ASSOCIATION OF AMERICA

[ Published five times a year ]

Volumes Online

VOLS. 1-122 (1884-2007), JSTOR

Vols. 117-28 (2002-13), MLAJournals.org

ONLINE INDEX

Vols. 1-128 (1884-2013)

MLA International Bibliography

Print Indexes

VoLS. 1-50, 1935; 51-60, 1945; 51-79, 1964

$$
\text { Editor }
$$

Simon GiKandi

Princeton University

Managing Editor

JUDY GOULDING

Associate Managing Editor ERIC WIRTH

Associate Editor

BARNEY LATIMER

Assistant Editors

Christiane Angeli

John D. Golbach

Advertising Manager and Submissions Associate

ANNABEL SCHNEIDER

Administrative Assistant Julia Gold

\section{Editorial Board}

Evelyne Ender, 2014

Hunter College, City University of New York RICHARD T. GRAY, 2013

University of Washington, Seattle JoHN KUCICH, 2013

Rutgers University, New Brunswick

Christopher LoOby, 2014

University of California, Los Angeles

Deidre Shauna Lynch, 2014 University of Toronto

LoIS PARKInson Zamora, 2013 University of Houston

Advisory Committee

SusAn Z. ANDRADE, 2014 University of Pittsburgh

Arturo Arias, 2014

University of Texas, Austin

EMILIE L. BergmanN, 2014

University of California, Berkeley

PATRICIA LyNn BIZZELL, 2014 College of the Holy Cross

MARCELlus Blount, 2015 Columbia University

CÉSAR BRAga-Pinto, 2013 Northwestern University

Martin Joseph Camargo, 2015 University of Illinois, Urbana

Julie ANn CARLSON, 2015

University of California, Santa Barbara

Catherine Ciepiela, 2013 Amherst College

Jenny Davidson, 2015

Columbia University (continued) 
Advisory Committee (continued)

Elizabeth Maddock Dillon, 2013 Northeastern University

JOSEPH ENTIN, 2013

Brooklyn College

Matt ERLIN, 2013

Washington University

StePhen M. FAllon, 2015

University of Notre Dame

GRANT FARRED, 2015 Cornell University

JosePh Francese, 2013

Michigan State University

Carla A. Freccero, 2014

University of California, Santa Cruz

DebJani Ganguly, 2015

Australian National University

Rebecca Garden, 2015, Upstate Medical

University, State University of New York

LAUREN M. E. GoODLAD, 2014

University of Illinois, Urbana

Maryemma Graham, 2014 University of Kansas

Judith Halberstam, 2015

University of Southern California

Shirley Brice Heath, 2014 Stanford University

Donald Hedrick, 2015

Kansas State University

PaUl Hopper, 2013

Carnegie Mellon University

Christoph IRMSCHER, 2013

Indiana University, Bloomington

Rosanne M. Kennedy, 2014

Australian National University

DeVoney LoOSER, 2013

University of Missouri, Columbia

Christopher M. LUPKe, 2015

Washington State University, Pullman

Deborah Lea Madsen, 2013

University of Geneva

Leerom Medovoi, 2014

Portland State University

BRINDA J. MeHTA, 2015 Mills College

JefFrey T. Nealon, 2013

Pennsylvania State University, University Park

Anuradha Dingwaney Needham, 2014

Oberlin College

DAVID PAN, 2013

University of California, Irvine

Marta C. Peixoto, 2014 New York University

Gema Pilar Pérez-Sánchez, 2014 University of Miami

Paula Rabinowitz, 2013

University of Minnesota, Twin Cities

KARLIS RACEVSKIS, 2015

Ohio State University, Columbus

José M. RodríGuez GarCíA, 2015 Duke University

GABRIELE M. SchWAB, 2015

University of California, Irvine

Miнoкo SUZUKI, 2014 University of Miami

RICHARD H. WATTS, 2014

University of Washington, Seattle

Carolyn S. Williams, 2013

Rutgers University, New Brunswick

DAVID JOSEPH WRISLEY, 2015

American University of Beirut

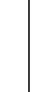 \\ JANUARY 2013}

156 Race and Revolution: Blackness in China's Long Twentieth Century SHU-MeI SHIH

163 Ferdinand Oyono in Vietnamese: Translation after Socialism and Colonialism

Ben Tran

170 "Monsieur Toundi-the Man": The Soviet Life of Ferdinand Oyono's Une vie de boy in Russian Translation

SARAh Valentine

178 The Afterlife of Oyono's Houseboy in the Swahili Schools Market: To Be or Not to Be Faithful to the Original

Ken Walibora Waliaula

185 Oyono in Slovene: Toundi's Visit to Yugoslavia

MONIKa ŽAGAR

\section{the changing profession}

\section{Reading in the Digital Age}

193 Redefining Reading: The Impact of Digital Communication Media NAOMI S. BARON

201 A Little Like Reading: Preference, Facebook, and Overwhelmed Interpretations

Michael CobB

207 Reading, in a Digital Archive of One's Own

Jim Collins

213 Reading Interface

JohanNa Drucker

221 Divination

Elaine Freedgood

226 Combining Close and Distant Reading: Jonathan Safran Foer's Tree of Codes and the Aesthetic of Bookishness

N. Katherine Hayles

232 Reading on the Move

Lutz KoepNick

238 "Words with Friends": Socially Networked Reading on Goodreads

Lisa NAKAMURA

244 Minutes of the MLA Executive Council

252 In Memoriam

256 Index of Advertisers

279 Abstracts 